\title{
Production of antioxidant peptides from Ferula asafoetida root protein
}

\begin{abstract}
The Ferula asafetida (F. Asafoetida) root exudates proteins were hydrolyzed using gastric digestive enzyme to identify the antioxidant peptides. F. Asafoetida root protein was hydrolyzed using gastrointestinal enzymes (pepsin, Papain, trypsin and $\alpha$-chymotrypsin) and purified by gel filtration chromatography (fast protein liquid chromatography, FPLC). The fractions F1, F2, F3, F6, F7, F8, and F9 were collected and screened for radical scavenging activity. Antioxidant activities of hydrolysate were evaluated using 2,2'-azinobis-(3ethylbenzothiazoline-6-sulfonic acid) (ABTS), ferric reducing antioxidant power assay (FRAP) and superoxide radical scavenging activity in enzyme-linked immunosorbent assay (ELISA) multimode reader. Results showed that the activity of quenched free radicals $\left(\mathrm{ABTS}^{+}, \mathrm{FRAP}\right.$ and superoxide) was altered in a concentration-dependent manner. Fraction F1 showed highest scavenging activity than that of other fractions and it showed comparatively enhanced reducing power activity with butylated hydroxyanisole. Among three assays, ABTS showed better result than that of others. Further studies are still needed to find out the amino acid sequence responsible for antioxidant activity.
\end{abstract}

Keywords: Ferula asafetida, enzyme hydrolysis, antioxidant peptides, FPLC, gastrointestinal enzymes, liquid chromatography, electrophoresis device, medicinal properties, digestive enzymes
Volume I Issue I - 2016

\author{
Chandrasekaran Prabaharan,' Munusamy \\ Thirumavalavan, ${ }^{2}$ Raman Pachaiappan' \\ 'Department of Biotechnology, SRM University, India \\ ${ }^{2}$ Graduate Institute of Environmental Engineering, National \\ Central University, Taiwan
}

\begin{abstract}
Correspondence: Raman Pachaiappan, Department of Biotechnology, School of Bioengineering, SRM University, Kattankulathur-603203, India, Tel +9l-9486433614, Fax +91-4427453903, Email pachaiappan.ra@ktr.srmuniv.ac.in
\end{abstract}

Co-Correspondence: Munusamy Thirumavalavan, Department of Biotechnology, School of Bioengineering, SRM University, Kattankulathur-603203, India, Tel +886-3-4227I5I-34658, Fax +886-3-4226742, Email mtvala@yahoo.com

Received: October 27, 2016 | Published: November 16,2016

\section{Introduction}

In recent years, there has been much importance placed on finding novel therapeutic agents from $F$. Asafoetida plant and it's common name is Asafoetida. It is commonly used as a traditional medicine in Iran, Afghanistan and India. It is herbaceous plant of the Umbelliferae family and its root contains oleo gum resin which has many medicinal properties. The resin is solid or semisolid with alliaceous odor and a bitter acrid taste, which comprises ferulic acid, umbelliferone, asaresinotannols, umbelliferone ethers, gums and volatile oils. The sulfides of volatile oils are responsible for the characteristic flavor of Asafoetida. ${ }^{1}$ Asafoetida is commonly used for cooking purpose as it is an indigenous medicine which cures sporadic disorder and stimulates digestion. Figure 1 shows the schematic representation of plant Ferula asafetida and its various applications. The free radicals are the main cause for oxidative damage to biomolecule such as DNA, proteins and lipids, which leads to many chronic diseases such as atherosclerosis, diabetes, aging, degenerative diseases and mainly cancer. ${ }^{2-5}$ Formation of free radicals such as superoxide anion $\left(\mathrm{O}_{2}^{-}\right.$ ) radical and hydroxyl $(\mathrm{OH})$ radical is an unavoidable consequence in aerobic organisms during respiration. Uncontrolled generated free radicals are very unstable, and react rapidly with the other groups or substances in the body, leading to cell or tissue injury. Numerous physiological and biochemical processes in the human body may produce oxygen-centered free radicals and other reactive oxygen species as byproducts.

In addition, numerous studies have revealed that uncontrolled lipid peroxidation is involved in the occurrence of numerous chronic diseases. ${ }^{6-8}$ There is still considerable argument regarding the direct intake of natural antioxidants has been associated with reduced risks of cancer, cardiovascular disease, diabetes, and other diseases related with ageing. ${ }^{9-13}$ Therefore, studying of natural plants specially bred for higher levels of antioxidant compounds is a realistic approach to increase dietary antioxidant intake. However such screening methods should be simple, inexpensive, rapidly performed, and provide a high degree of precision. Many studies have been investigated the antioxidant property of hydrolysates from different plant and animal sources like sunflower protein, alfalfa leaf protein, corn gluten meal, egg-yolk protein, algae protein, mushroom. ${ }^{14}$ The defensive effects of natural antioxidants in plants and animals are related to different constituents. These techniques have shown different results and no correlations were obtained and discussed in details. Hence, in this study we made an attempt to obtain such hydrolysates from $F$. Asafoetida root protein and to study their antioxidant activity using different methods. The biological activity of a peptide is widely recognized to be based on amino acid composition. ${ }^{15}$ The bioactive peptides are commonly made up of 3-20 amino acids per peptide, which are present in the large protein in inactive sequences and become active when they get hydrolyzed by digestive enzymes, microbial enzymes or during food processing. ${ }^{16}$ Enzymatic hydrolysis of proteins is one of the significant approaches used to discharge bioactive peptides and is widely applied to study functional and nutritional properties of protein sources. ${ }^{6}$ These peptides can be directly used in the formulation of functional foods and nutraceuticals to prevent damage related to oxidative stress in human disease conditions. The main objectives of the current study were to obtain a protein from the root exudates of the F. Asafetida, enzymatic hydrolysis of such isolated protein using gastrointestinal enzymes and finally to investigate the antioxidant property of obtained peptides from F. Asafoetida root protein. This approach is simple, effective and inexpensive and in this work the antioxidant activity was directly correlated with concentration factor. Therefore, it would be an appropriate technique for determining antioxidant in F. Asafoetida root extract. 


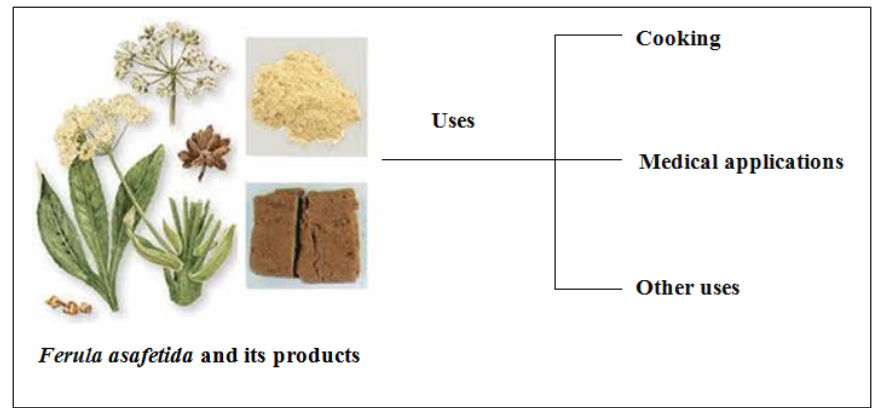

Figure I Schematic representation of products and uses of plant Ferula Asafetida.

\section{Materials and methods}

\section{Chemicals}

Enzymes were obtained commercially as follows; Papain from papaya latex (Merck, activity: >30,000 USP units/mg of protein calculated using hemoglobin as a substrate), pepsin from porcine gastric mucosa (Calbiochem, activity: $3000 \mathrm{U} / \mathrm{mg}$ of protein calculated using hemoglobin as a substrate), trypsin from porcine pancreas (Sigma-Aldrich, activity $>10000 \mathrm{UN} / \mathrm{mg}$ of protein calculated using BAEE as a substrate) and $\alpha$-chymotrypsin from bovine pancreas (Sigma-Aldrich, activity $>2000-3000 \mathrm{UN} / \mathrm{mg}$ of protein calculated using ATEE as a substrate). Superdex-G-30 matrix was obtained from GE Healthcare Bio-Sciences AB, Sweden. The reagents used for the antioxidant assays such as 2,2'-azinobis-(3-ethylbenzothiazoline-6sulfonic acid) (ABTS), ferrozine, ferrous chloride, ferric chloride, (2, 4, 6- tripyridyl-s-triazine) (TPTZ) and butylated hydroxyanisole (BHA) were purchased from Sigma-Aldrich, USA. All other chemicals and reagents used were of the highest grade available commercially.

\section{Plant collection and protein extraction}

The root exudate of $F$. Asafoetida was obtained from Iran market. Exudate $(250 \mathrm{~g})$ was soaked in distilled water overnight and stirred to obtain a consistent solution. Preliminary level of filteration was done to remove the larger particles and debris from the solution. The obtained filterate was centrifuged at $18000 \mathrm{rpm}$ for $30 \mathrm{~min}$, supernatant was collected and stored at $4{ }^{\circ} \mathrm{C}$. Precipitation of proteins was done using ammonium sulphate at $80 \%$ saturation and kept for precipitating overnight at $4{ }^{\circ} \mathrm{C}$. The precipitated proteins were separated through centrifugation at $10000 \mathrm{rpm}$ for $30 \mathrm{~min}$. The pellet was dissolved in $15 \mathrm{ml}$ of water and subjected to dialysis using $3.5 \mathrm{kDa}$ MWCO dialysis centrifugation tube (Merck Millipore, Germany). The precipitated proteins were lyophilised (Lyodel Freeze Dryer Model: DPRG$1 \mathrm{GH})$ and stored at $-20^{\circ} \mathrm{C}$ for further use. Protein concentration was estimated by the Bradford method using bovine serum albumin (BSA) as a standard protein. The absorbance of the protein-dye complex was measured at a wavelength of $595 \mathrm{~nm}$.

\section{Glycine SDS-PAGE}

F. Asafoetida proteins was separated through the glycine SDSPAGE (14\% separating gel and 4\% stacking gel) in the electrophoresis device (GeNei, India). The separation was controlled with $100 \mathrm{~V}$ and allowed to run until the dye reaches the glycine SDS-PAGE bottom. The protein bands were stained with silver staining. Protein patterns were observed and documented using Bio-Rad (ChemiDoc XRS+ imaging system, USA) and compared with the protein marker 43-3.5 $\mathrm{kDa}$.
Table I The optimum conditions of enzymatic hydrolysis of F.Asafoetida root proteins with various enzymes

\begin{tabular}{llll}
\hline Enzymes & Buffer & pH & Temperature $\left({ }^{\circ} \mathbf{C}\right)$ \\
\hline \multirow{2}{*}{ Papain } & $\begin{array}{l}50 \mathrm{mM} \mathrm{Na}_{2} \mathrm{HPO}_{4}- \\
\mathrm{NaH}_{2} \mathrm{PO}_{4}\end{array}$ & 6.5 & 37 \\
Pepsin & $10 \mathrm{mMTris}-\mathrm{HCl}$ & 2 & 37 \\
Trypsin & $50 \mathrm{mMTis}-\mathrm{HCl}$ & 7.8 & 37 \\
a-chymotrypsin & $0.1 \mathrm{mM}$ Tris- $\mathrm{HCl}$ & 7.8 & 37 \\
\hline
\end{tabular}

\section{Enzymatic hydrolysis}

F. Asafoetida root exudates protein was hydrolyzed enzymatically using simulated gastrointestinal fluid with enzymes (Papain, pepsin, trypsin, and $\alpha$-chymotrypsin) which were optimized as shown in Table 1. The enzyme: substrate ratio $(\mathrm{w} / \mathrm{w})$ was 1:50 incubated at different time periods $(30,60,90,120$ and 180s) and then heated for $2 \mathrm{~min}$ at $100^{\circ} \mathrm{C}$. The digested protein was separated in resolving $14 \%$ Laemmli, Glycine SDS-PAGE, followed by silver staining. Degree of hydrolysis was determined by measuring the nitrogen content soluble in $10 \%$ trichloroacetic acid as described previously. ${ }^{6}$

\section{Separation of protein using fast protein liquid chromatography (FPLC)}

F. Asafoetida root exudates hydrolyzed protein was loaded onto a Gel filtration column (Superdex 30 prep grade) connected to a fast protein liquid chromatography (FPLC). ÄKTApurifierTM chromatography system (ÄKTA purifier Frac-950 at a flow rate of $2 \mathrm{~mL}$ $\mathrm{min}^{-1}$ ) from GE Healthcare was used for fast and reliable separation of proteins. The column was equilibrated and eluted with $20 \mathrm{mM}$ phosphate buffer ( $\mathrm{pH}$ 7.2). The separation profile was monitored at wavelengths 280 and $220 \mathrm{~nm}$ using a UV detector. Each hydrolyzed protein was collected, lyophilized and stored at $-20^{\circ} \mathrm{C}$. These fractions were tested for antioxidant activity.

\section{Antioxidant activity assay}

ABTS radical-scavenging activity assay: The free radical scavenging capacity of hydrolyzedprotein fractions was studied using the ABTS radical cation $\left(\mathrm{ABTS}^{+}\right)$decolorization assay, which is based on the reduction of $\mathrm{ABTS}^{+}$radicals by antioxidants property of hydrolyzed protein. This assay was carried out in 96 well ELISA plates. ABTS $7 \mathrm{mM}$ concentration was dissolved in deionized water. $\mathrm{ABTS}^{+}$was produced by reacting ABTS solution with $2.45 \mathrm{mM}$ potassium persulfate (final concentration) and allowing the mixture to stand in the dark condition at room temperature for 12-16h, before use. In the experiments, the $\mathrm{ABTS}^{+}$solution was diluted in deionized water or ethanol to $0.7 \AA$ at $734 \mathrm{~nm}$ using Multiskan GO (Thermo Scientific, USA). An appropriate solvent blank reading was taken. The different concetration $(2.5 \mu \mathrm{g}$ to $30 \mu \mathrm{g})$ of hydrolyzed protein solution $20 \mu \mathrm{L}$ was added to $190 \mu \mathrm{L}$ of $\mathrm{ABTS}^{+}$solution, follwed by incubation for $37^{\circ} \mathrm{C}$ at $30 \mathrm{~min}$. The absorbance reading was taken at $734 \mathrm{~nm}$ and plotted against the linear standard curve between $20-800 \mu \mathrm{M}$ of Trolux soluion. ${ }^{17}$ All solutions were freshly prepared before expreiments and performed in triplicate. The percentage of inhibition of $\mathrm{ABTS}^{+}$was calculated using the formula

$$
\text { Inhibiton } \%=\frac{(\mathrm{AB}-\mathrm{AS})}{\mathrm{AB}} \times 100
$$


Where, $\mathrm{AB}$ is the absorbance of the blank sample and AS is the absorbance of the sample.

Ferric reducing antioxidant power assay (FRAP): The FRAP assay was performed according to modified method of Thaipong et al. ${ }^{17}$ The stock solutions included $300 \mathrm{mM}$ acetate buffer $\left(3.1 \mathrm{~g} \mathrm{C}_{2} \mathrm{H}_{3} \mathrm{NaO}_{2} .3 \mathrm{H}_{2} \mathrm{O}\right.$ and $\left.16 \mathrm{~mL} \mathrm{C}_{2} \mathrm{H}_{4} \mathrm{O}_{2}, \mathrm{pH} 3.6\right), 10 \mathrm{mM} \mathrm{TPTZ}$ (2, 4, 6-tripyridyl-s-triazine) solution in $40 \mathrm{mM} \mathrm{HCl}$, and $20 \mathrm{mM} \mathrm{FeCl}_{3} \cdot 6 \mathrm{H}_{2} \mathrm{O}$ solution. The working solution was freshly prepared by mixing $25 \mathrm{~mL}$ acetate buffer, $2.5 \mathrm{~mL}$ TPTZ solution, and $2.5 \mathrm{~mL} \mathrm{FeCl} \cdot 6 \mathrm{H}_{2} \mathrm{O}$ solution and heated at $37^{\circ} \mathrm{C}$ before use. The hydrolyzed protein fractions $(25 \mu 1)$ were allowed to react with $175 \mu \mathrm{L}$ of the FRAP solution for 30min in the dark condition. This assay was carried out in 96 well ELISA plates. The absorbance reading of the colored product (ferrous tripyridyl triazine complex) were measured at $593 \mathrm{~nm}$ using Multiskan GO (Thermo Scientific, USA) and plotted against the linear standard curve between $20-800 \mu \mathrm{M}$ of Trolux soluion. All solutions were freshly prepared before expreiments and performed in triplicate.

Superoxide radical $\mathrm{O}_{2}$-scavenging activity assay: Superoxide radical scavenging activity was preformed according to a previously described method by Trisha et al. ${ }^{18}$ The reaction mixture consisted of $5.7 \mathrm{~mL}$ of $50 \mathrm{mM}$ Tris-HCl, $1 \mathrm{mM}$ EDTA (ethylene diamine tetraacetic acid) buffer, $\mathrm{pH} 8.6$ (incubated at $25^{\circ} \mathrm{C}$ for $20 \mathrm{~min}$ ), $10 \mu \mathrm{g}$ of proteins from fractions and $0.1 \mathrm{~mL}$ of $5 \mathrm{mM}$ pyrogallol solution (added in sequence). Pyrogallol was just used to initiate the reaction. The rate of pyrogallol antioxidation was measured at $320 \mathrm{~nm}$ using a spectrophotometer, which was its optical density and recorded every $30 \mathrm{~s}$ for $4 \mathrm{~min}$. The capacity for scavenging superoxide anion radicals was calculated as

$$
\text { Inhibiton } \%=\frac{(\mathrm{AC}-\mathrm{AS})}{\mathrm{AC}} \times 100
$$

Where, AC is the change in absorbance per minute of the control solution containing pyrogallol and buffer, and AS is the change in absorbance per minute of the sample.

Reducing power assay: The reducing power of hydrolyzed protein fractions to reduce $\mathrm{Fe}$ (III) was measured according to the method of Ali Bougatef et al..$^{19}$ In short, $0.5 \mathrm{~mL}$ of hydrolyzed protein fractions and $0.2 \mathrm{~mL}$ of $200 \mathrm{mM}$ phosphate buffer $(\mathrm{pH}$ 6.6) were mixed with $50 \mu \mathrm{L}$ of $1 \% \mathrm{~K}_{3} \mathrm{Fe}(\mathrm{CN})_{6}$. The mixture was incubated at $50^{\circ} \mathrm{C}$ for $20 \mathrm{~min}$ and mixed with $0.1 \mathrm{~mL}$ of $10 \%$ trichloroacetic acid (TCA) followed by centrifugation at $10000 \mathrm{rpm}$ for $10 \mathrm{~min}$. Further, $0.2 \mathrm{~mL}$ of the supernatant was collected and mixed with $0.2 \mathrm{~mL}$ of water followed by $20 \mu \mathrm{L}$ of $0.1 \% \mathrm{FeCl}_{3}$. After $10 \mathrm{~min}$ of incubation at room temperature, the absorbance at $700 \mathrm{~nm}$ was measured for the resulting Prussian blue solution. The obtained results were compared with the BHA (butylated hydroxy anisole) standard. A higher absorbance value indicates greater reducing power.

\section{Results and discussions}

\section{Extraction and hydrolysis of F.Asafoetida root exudates protein}

After water extraction of $F$. Asafoetida root exudates protein, it was quantified using Bradford's method..$^{20}$ Finally, lyophilized powder of $150 \mathrm{mg} / \mathrm{g}$ of protein was obtained. The molecular sizes of lyophilized proteins were determined using glycine SDS-PAGE as shown in Figure 2. As shown in Figure 2, the gel profile showed a lot of proteins including polypeptides and peptides in the molecular sizes in the range of $43 \mathrm{KDa}$ to $3.5 \mathrm{KDa}$. Result showed that the major large protein molecules were above $10 \mathrm{kDa}$ and minor group was small molecules less than $10 \mathrm{kDa}$, which are also called as peptides. F. Asafoetida root exudates protein was hydrolyzed using in vitro gastrointestinal enzyme by varying the time period and enzyme: substrate (w/w) concentration. F. Asafoetida root exudates proteins were separately hydrolyzed by papain, pepsin, trypsin, and $\alpha$-chymotrypsin for the production of antioxidant peptides. The lyophilized $F$. Asafoetida protein hydrolysate was dissolved in $20 \mathrm{mM}$ sodium phosphate buffer ( $\mathrm{pH} 7.2)$, and loaded onto a Superdex 30 column using fast protein liquid chromatography (FPLC). Fraction peaks were monitored for absorbance at 220 and $280 \mathrm{~nm}$ and each fraction were collected at rate of $2 \mathrm{~mL} / \mathrm{min}$. Figure 3 shows the elution profile of hydrolysate produced by pepsin digested protein. Totally 9 pooled fractions were collected based on peaks, lyophilized and tested for antioxidant activity. The gastric enzyme pepsin digested $26 \mathrm{kDa}$ F. Asafoetida protein into $14 \mathrm{kDa}$ and $6.5 \mathrm{kDa}$ accumulation and the maximum digestion was attained at $180 \mathrm{~min}$. The enzyme Papain digested $26 \mathrm{kDa} F$. Asafoetida protein into $3.5 \mathrm{kDa}$ accumulation at $120 \mathrm{~min}$. The pancreatic enzymes such as trypsin and $\alpha$-chymotrypsin didn't show any digestion at maximum time $180 \mathrm{~min}$. The degree of hydrolysis for $F$. Asafoetida root exudates protein was tested using the gastrointestinal enzymes. The protein degradation by proteolytic enzymes was estimated by assessing the degree of hydrolysis (DH) and it was observed that pepsin showed higher DH compared with other enzymes as shown in Figure 4. The protein degradation by proteolytic enzymes was observed to be $21.5 \%$ and $13.2 \%$ for pepsin and Papain. The other enzymes such as trypsin and $\alpha$-chymotrypsin showed lower than $5 \%$ degree of hydrolysis. As a result, enzyme pepsin was selected for further process. As shown in Figure 5, pepsin hydrolysates and crude protein antioxidant activity was compared to the natural antioxidant trolox and ascorbic acid. Results also depicted that pepsin hydrolysates antioxidant activity was comparable with the trolox antioxidant activity. Further, it was assumed that protein molecules are responsible for antioxidant agents, because the antioxidant activity against ABTS radicals scavenging activity increases significantly with the $F$. Asafoetida hydrolysates concentration. In numerous literatures it has been reported that the highest antioxidant activity of proteins molecular weight was under $10 \mathrm{kDa} \cdot{ }^{19,21-23}$
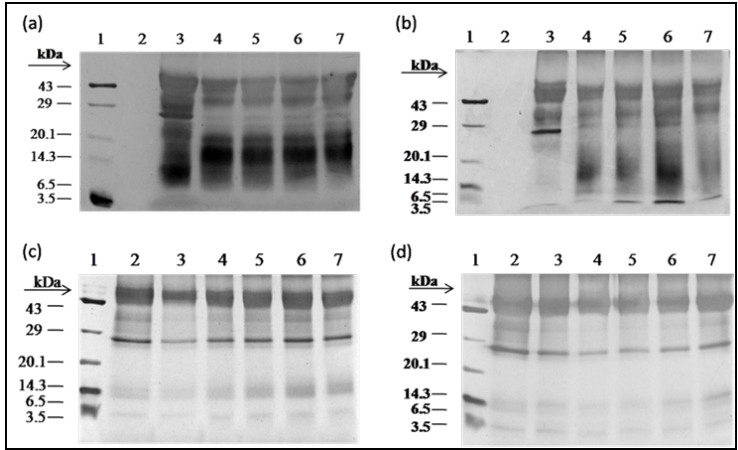

Figure 2 (a) Pepsin and (b) Papain digested root proteins of $F$. Asafoetida separated on glycine SDS-PAGE (I4\%). Lane I is the standard protein marker; Lane 2 is the enzyme control; Lane 3 is the protein control; Lane 4-7 is 30, 60,90 and $120 \mathrm{~min}$ of different digestion period of F. Asafoetida root protein. (c) Trypsin and (d) $\alpha$-Chymotrypsin digested root protein of $F$. Asafoetida separated on glycine SDS-PAGE (I4\%). Lane I is the standard protein marker; Lane 2 is the protein control; Lane 4-7 is 30,60,90,120 and I80min of different digestion period of F.Asafoetida protein. 


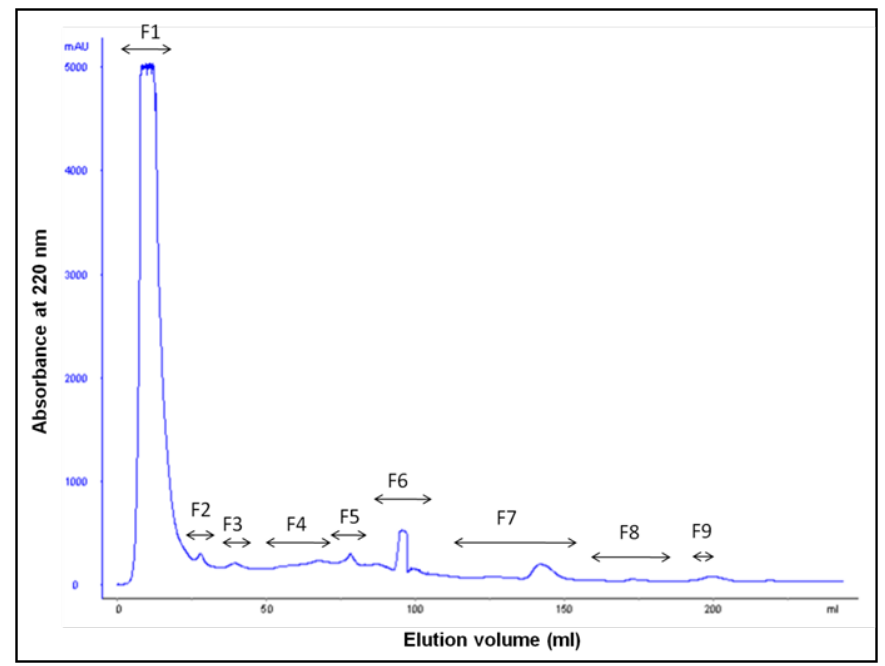

Figure 3 Elution profile of hydrolysate produced by pepsin digested protein separated by gel filtration chromatography on superdex 30 column was equilibrated and eluted with $20 \mathrm{mM}$ of sodium phosphate buffer, $\mathrm{pH} 7.2$ at a flow rate of $2 \mathrm{~mL} / \mathrm{min}$.

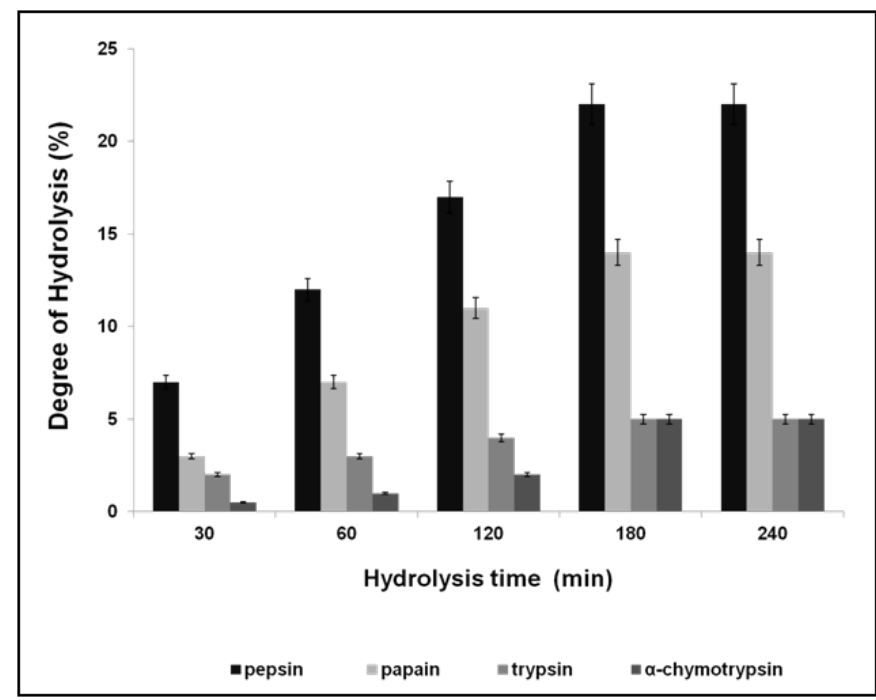

Figure 4 Hydrolysis curves of F.Asafoetida root proteins treated with various enzymes at different time periods.

\section{Antioxidant activity}

After purification by FPLC, nine fractions were collected and tested for antioxidant activity as shown in Figure 6. ABTS, FRAP and superoxide radical scavenging activity was used to estimate the antioxidant mechanism, due to the rapid reaction process (i.e. within 5 to 10mins). The antioxidant activities of hydrolyzed factions were tested using ABTS, FRAP, Superoxide assay. The $\mathrm{ABTS}^{+}$radical scavenging activity of pepsin digested $F$. Asafoetida root exudates protein was tested. The relative antioxidant ability to scavenge the radical $\mathrm{ABTS}^{+}$has been compared to the standards trolox and ascorbic acid, which is an excellent tool for determining the antioxidant activity. The result showed that there was an increase in the ABTS radical scavenging capacity of $F$. Asafoetida root protein exudates up to a concentration of $25 \mu \mathrm{g} / \mu 1$ followed by comparatively low increase, with further increases in concentration. The result clearly depicted that $\mathrm{ABTS}^{+}$assay for Fraction (F1, F2, F6) had maximum activity of
$92,75,81 \%$ and F7, F8, F9 was $<60 \%$ of activity. The other assay, FRAP showed F1, F2, F6 fraction had a maximum activity of 73, 60, $58 \%$ and F7, F8, F9 had activity of $<40 \%$. Finally, the reproducibility assay of superoxide scavenging activity showed that F1, F2, F3 had maximum activity of $81,65,72 \%$ and F7, F8, F9 had activity of $<50 \%$. From the result, Fraction 1 showed higher antioxidant properties and exhibited considerable scavenging potencies on $\mathrm{ABTS}^{+}$, FRAP, superoxide assays. Among three assays carried out in this study, ABTS showed comparatively enhanced activity than that of others. Another advantage of the ABTS was that extracts reacted rapidly with ABTS. Among the fractions, fraction 1 showed the highest peak and higher antioxidant activity compared to other fractions in three different antioxidant assays. As the response of antioxidants depends on many factors, the antioxidant activity of the hydrolysates was characterized using different assays based on different antioxidant mechanisms. The ABTS radical cation scavenging assay is applicable to both lipophilic and hydrophilic compounds and has been widely used to assess antioxidant activity. ${ }^{24}$ ABTS assay is an excellent tool for determining the antioxidant activity of hydrogen-donating antioxidants (scavengers of aqueous phase radicals) and of chain breaking antioxidants (scavenger of lipid peroxyl radicals). ${ }^{25}$

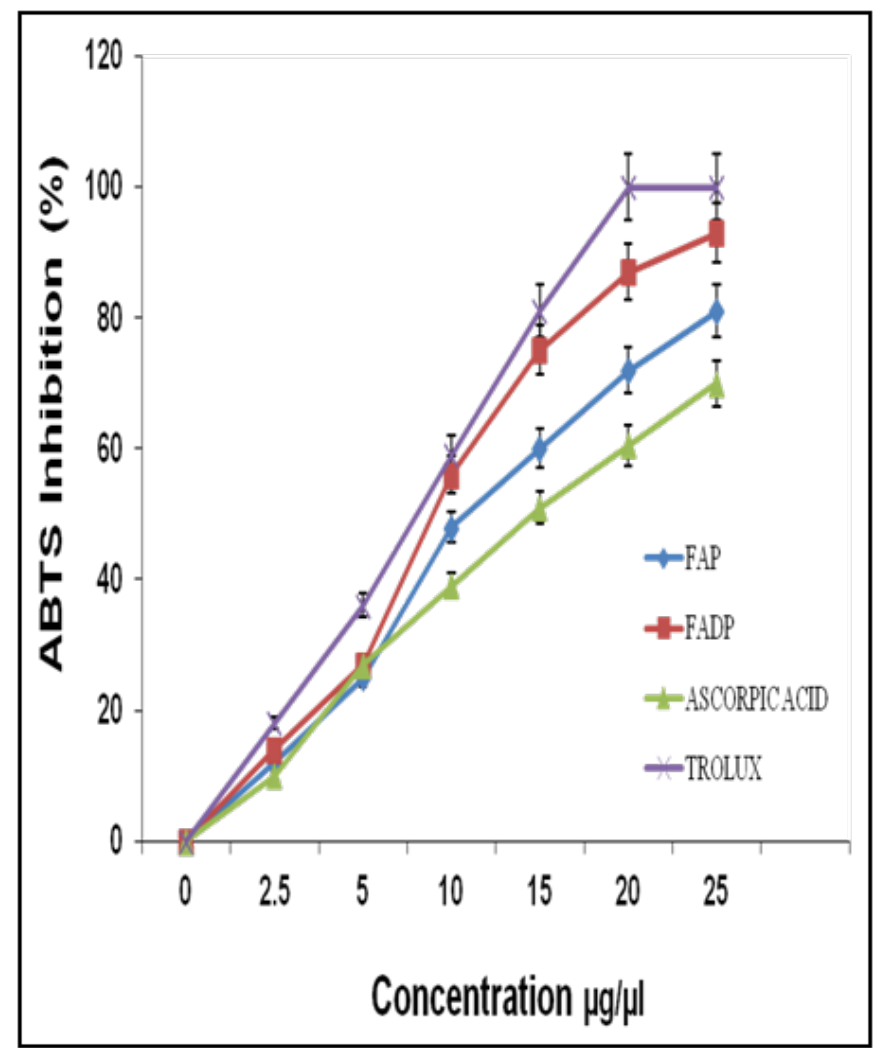

Figure 5 ABTS radical-scavenging activity of $F$. Asafoetida root exudates proteins and pepsin digested protein at different concentrations (Trolux and ascorbic acid were used as positive controls)

The antioxidant activity of hydrolysates is mainly influenced by their amino acid sequence, which depends on the protease specificity. ${ }^{26-29}$ It is reported that both large peptides and short ones can protect from oxidation by various mechanisms, including metal Chelation and formation of oil droplets around membranes. ${ }^{29}$ The ferric reducing antioxidant power, generally measures the antioxidant effect of any substance in the reaction medium as its reducing ability. 
At low $\mathrm{pH}$, when a ferric tripyridyl triazine complex is reduced to the ferrous form, an intense blue color with an absorption maximum at $593 \mathrm{~nm}$ develops. The reaction is nonspecific and any half-reaction which has a less-positive redox potential, under reaction conditions, than the $\mathrm{Fe}^{\mathrm{III}} / \mathrm{Fe}^{\mathrm{II}}$-TPTZ half-reaction will drive $\mathrm{Fe}^{\mathrm{III}}$-TPTZ reduction. Test conditions favor the reduction of the complex and thereby, color development, provided that a reductant (antioxidant) is present. ${ }^{30}$ Superoxide radical is known to be very harmful to cellular components as a precursor of more reactive oxidative species, such as single oxygen and hydroxyl radicals. ${ }^{31}$ Furthermore, superoxide radical is considered to play an important role in the peroxidation of lipids. The reducing power assay is often used to evaluate the ability of antioxidant to donate electron. ${ }^{32}$ Further, detailed studies of the amino acid sequence responsible for the antioxidant activity have to be elucidated.

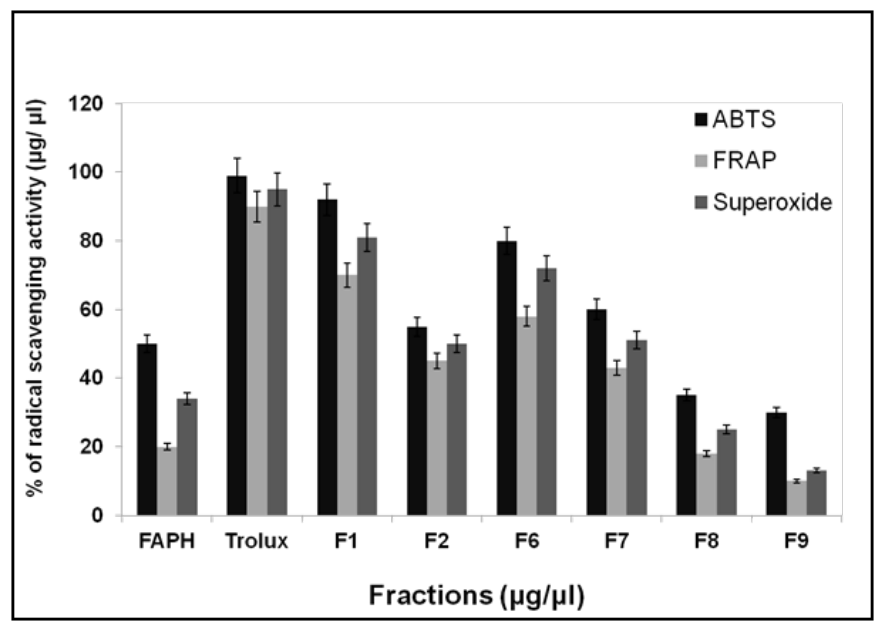

Figure 6 Measurement of antioxidant activity of $F$. Asafoetida root protein fractions after gel filtration chromatography using $\mathrm{ABTS}^{+}$, FRAP and superoxide radical scavenging (Trolux was used as positive control)

\section{Reducing power assay}

The reducing power assay of hydrolyzed protein was investigated following the method reported by Zhu et al..$^{22}$ and the results are shown in Figure 7. To measure the reductive ability of protein hydrolysates, different fraction were studied for the reduction of $\mathrm{Fe}^{3+}$ to $\mathrm{Fe}^{2+}$. The reducing power of fraction (1) was excellent, which increased steadily with increase in the concentration of samples. At $3 \mathrm{mg}$, the power of reducing was higher than 0.38 . Thus, this data supports the antioxidant activity of fractions

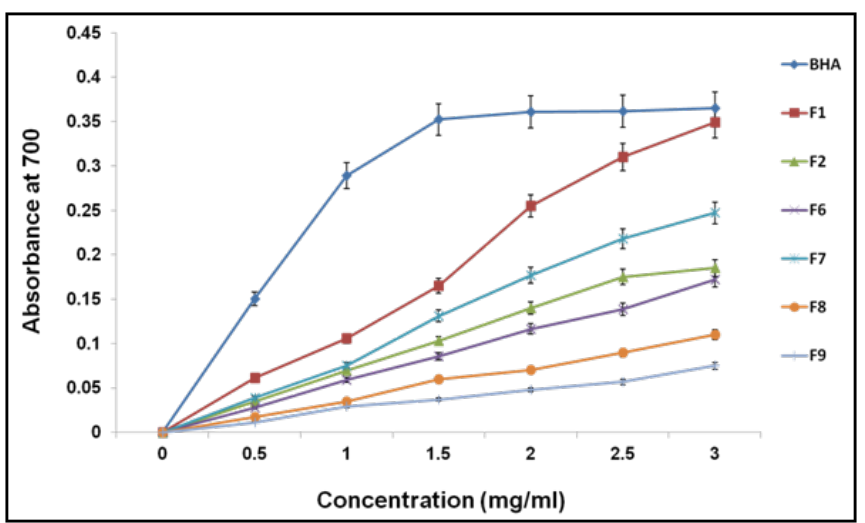

Figure 7 Reducing power activity of different fraction at various concentrations (BHA was used as positive control).

\section{Conclusion}

The enzymatic hydrolysis of $F$. Asafoetida through the action of pepsin provided a high proportion of peptides in the range of $10 \mathrm{kDa}$ $6.5 \mathrm{kDa}$. The hydrolysis degree of pepsin digested $F$. Asafoetida showed maximum $(22 \%)$ hydrolysis for 180min. After purification using FPLC, the hydrolysates showed more antioxidant activity in three different radical scavenging assays. The ABTS, FRAP, and superoxide radical assays gave comparable results for the antioxidant activity measured in F. Asafoetida root protein exudates. The ABTS technique was simple, rapidly performed and showed high reproducible activity. Therefore, it would be an appropriate technique for determining antioxidant in F. Asafoetida root protein exudates. These hydrolysates can be used to formulate functional food ingredient in pharmaceutical and nutraceuticals. However, further detailed studies on its peptide fractions with regard to amino acid sequence, antioxidant activity in vivo and the different antioxidant pathway mechanisms are needed.

\section{Acknowledgements}

The authors express gratefulness to Department of Biotechnology, School of Bioengineering SRM University for providing the facilities to execute these studies.

\section{Conflict of interest}

Author declares that there is no conflict of interest.

\section{References}

1. Al-Jenoobi FI, Al-Thukair AA, Alam MA, et al. Modulation of CYP2D6 and CYP3A4 metabolic activities by Ferula asafoetida resin. Saudi Pharmaceut J. 2014;22(6):564-569.

2. Cai Y, Luo Q, Sun M, et al. Antioxidant activity and phenolic compounds of 112 traditional Chinese medicinal plants associated with anticancer. Life Sci. 2004;74(17):2157-2184.

3. Halliwell B. Free radicals, antioxidants, and human disease: curiosity, cause, or consequence? Lancet. 1994;344(8924):721-724.

4. Niki E. Free radicals, antioxidants, and cancer. In: Ohigashi, editor. Food Factors for Cancer Prevention. Tokyo: Springer; 1997. p. 55-57.

5. Poulsen HE, Prieme H, Loft Loft S. Role of oxidative DNA damage in cancer initiation and promotion. Eur J Cancer Prev. 1998;7(1):9-16.

6. Je JY, Qian ZJ, Byun HG, et al. Purification and characterization of an antioxidant peptide obtained from tuna backbone protein by enzymatic hydrolysis. Proc Biochem. 2007;42(2007):840-846.

7. Pryor WA. Free radical biology: xenobiotics, cancer, and aging. Ann N Y Acad Sci. 1982;393:1-22.

8. Butterfield D, Castegna A, Pocernich C, et al. Nutritional approaches to combat oxidative stress in Alzheimer's disease. J Nutr Biochem. 2002;13(8):444-461.

9. Hertog MG, Kromhout D, Aravanis C, et al. Flavonoid intake and longterm risk of coronary heart disease and cancer in the seven countries study. Arch Intern Med. 1995;155(4):381-386.

10. Kuo SM. Dietary flavonoid and cancer prevention: evidence and potential mechanism. Crit Rev Oncog. 1997;8(1):47-69.

11. JW Mclarty. Antioxidants and cancer: The epidemiologic evidence. In: Garewal HS, editor. Antioxidants and Disease Prevention. USA:CRC Press; 1997. p. 45-66.

12. Yang CS, Landau JM, Huang MT, et al. Inhibition of carcinogenesis by dietary polyphenolic compounds. Annu Rev Nutr. 2001;21:381-406. 
13. Sun J, Chu YF, Wu X, et al. Antioxidant and antiproliferative activities of common fruits. J Agric Food Chem. 2002;50(25):7449-7454.

14. Sarmadi BH, Ismail A. Antioxidative peptides from food proteins A review. Peptides. 2010;31(10):1949-1956.

15. Korhonen H, Pihlanto A. Food-derived bioactive peptides-opportunities for designing future foods. Curr Pharm Des. 2003;9(16):1297-1308.

16. Jiang $\mathrm{H}$, Tong $\mathrm{T}$, Sun $\mathrm{J}$, et al. Purification and characterization of antioxidative peptides from round scad (Decapterus maruadsi) muscle protein hydrolysate. Food Chem. 2014;154:158-163.

17. Thaipong K, Boonprakob U, Crosby $\mathrm{K}$, et al. Comparison of ABTS, DPPH, FRAP, and ORAC assays for estimating antioxidant activity from guava fruit extracts. J Food Composition and Analysis. 2006;19(6-7):669-675.

18. Trisha LP, Chibuike CU, Rotimi EA. Amino Acid Composition and Antioxidant Properties of Pea Seed (Pisum sativum L.) Enzymatic Protein Hydrolysate Fractions. J Agric Food Chem. 2010;58(8):4712-4718.

19. Bougatef A, Hajji M, Balti R, et al. Antioxidant and free radicalscavenging activities of smooth hound (Mustelus mustelus) muscle protein hydrolysates obtained by gastrointestinal proteases. Food Chemistry. 2009;114(4):1198-1205.

20. Bradford MM. A rapid and sensitive method for the quantitation of microgram quantities of protein utilizing the principle of protein-dye binding. Anal Biochem. 1976;72:248-254.

21. Xie Z, Huang J, Xu X, et al. Antioxidant activity of peptides isolated from alfalfa leaf protein hydrolysate. Food Chemistry. 2008;111(2):370-376.

22. Zhu K, Zhou H, Qian H. Antioxidant and free radical-scavenging activities of wheat germ protein hydrolysates (WGPH) prepared with alcalase. Process Biochemistry. 2006;41(6):1296-1302.

23. Najafian L, Babji AS. Isolation, purification and identification of three novel antioxidative peptides from patin (Pangasius sutchi) myofibrillar protein hydrolysates. LWT-Food Science and Technology. 2015;60(1):452-461.
24. Arnao MB. Some methodological problems in the determination of antioxidant activity using chromogen radicals: A practical case. Trends in Food Science and Technology. 2000;11(11):419-421.

25. Leong L P, Shui G. An investigation of antioxidant capacity of fruits in Singapore markets. Food Chemistry. 2002;76(1):69-75.

26. Chen HM, Muramoto K, Yamauchi F. Structural analysis of antioxidative peptides from soybean $\boldsymbol{\beta}$-conglycinin. J Agric Food Chem. 1995;43(3):574-578.

27. Chiang WD, Shih CJ, Chu YH. Functional properties of soy protein hydrolysate produced from a continuous membrane reactor system. Food Chemistry. 1999;65(2):189-194.

28. Kou X, Gao J, Xue Z, et al. Purification and identification of antioxidant peptides from chickpea (Cicer arietinum L.) albumin hydrolysates. $L W T$ Food Science and Technology. 2013;50(2):591-598.

29. Pena-Ramos EA, Xiong YL. Antioxidant activity of soy protein hydrolysates in a liposomal system. J Food Sci. 2002;67(8):2952-2956.

30. Lei Q, Bei-Wei Z, Da-Yong Z, et al. Preparation and antioxidant activity of enzymatic hydrolysates from purple sea urchin (Strongylocentrotus nudus) gonad.LWT-Food Science and Technology.2011;44(4):1113-1118.

31. Li Y, Jiang B, Zhang T, et al. Antioxidant and free radical-scavenging activities of chickpea protein hydrolysate (CPH). Food Chem. 2008;106(2):444-450.

32. Yildirim A, Mavi A, Oktay M, et al. Comparison of antioxidant and antimicrobial activities of tilia (Tilia argentea Desf Ex DC), sage (Salvia triloba L.) and black tea (Camellia sinensis) extracts. J Agric Food Chem. 2000;48(10):5030-5034. 